\title{
Spices addition as strategy for polyphenol increase in baked product
}

\author{
Adição de especiarias como estratégia para aumento de compostos fenólicos em pão de mel \\ Adicion de especias como estratégia para el aumento de compuestos fenólicos em pan de miel
}

Received: 02/11/2021 | Reviewed: 02/20/2021 | Accept: 03/02/2021 | Published: 03/09/2021

\author{
Daiana Freitas da Silva \\ ORCID: https://orcid.org/0000-0002-3851-6083 \\ Universidade Federal do Rio de Janeiro, Brazil \\ E-mail: daianafreitasnutri@gmail.com \\ Ana Luísa Kremer Faller \\ ORCID: https://orcid.org/0000-0002-4891-1730 \\ Universidade Federal do Rio de Janeiro, Brazil \\ E-mail: ana.faller@nutricao.ufrj.br
}

\begin{abstract}
Spices are a rich source of polyphenols and when consumed regularly in the diet contribute to the beneficial health effects of these bioactive compounds. The aim of this study was to elaborate a baked product, honeybreads, without spices, control honeybread (CHB) and with ) the addition of spices, spiced honeybread (SHB, estimate their polyphenol content and evaluate their sensory acceptance. The macronutrient composition was calculated using the Brazilian Food Composition Database and phenolic compounds content calculated based on Phenol-Explorer 3.0 database. For sensory evaluation, a consumer panel was established, and a seven-point structured hedonic scale applied for: aroma, texture, appearance, taste and total acceptance. Each formulation yielded seventy $16 \mathrm{~g}$ servings with similar calories. The total phenolic compound content, per serving, of SHB was $11,198 \mathrm{mg}$ and for CHB $9,483 \mathrm{mg}$, content approximately $18 \%$ higher with the addition of spices. Both formulations showed good acceptability based on the acceptability index with over $75 \%$ on every parameter. Selection of specific ingredients can positively impact polyphenol content in baked products without compromising sensory characteristics.
\end{abstract}

Keywords: Spices; Polyphenol; Sensory evaluation; Baked products.

\section{Resumo}

Especiarias são importantes fontes de compostos fenólicos e, quando consumidas regularmente na dieta, contribuem para os efeitos benéficos desses compostos bioativos à saúde. O objetivo deste estudo foi elaborar um produto de panificação, pão de mel, sem adição de especiarias, pão de mel controle (CHB) e com adição de especiarias, pão de mel com especiarias (SHB), estimar o aporte de polifenóis e avaliar a aceitação sensorial das duas formulações. A composição de macronutrientes foi calculada usando a Tabela Brasileira de Composição de Alimentos e o conteúdo de compostos fenólicos calculado com base no banco de dados Phenol-Explorer 3.0. Para avaliação sensorial, foi estabelecido um painel de consumidores e aplicada uma escala hedônica estruturada de sete pontos para: aroma, textura, aparência, sabor e aceitação total. Cada formulação rendeu setenta porções de $16 \mathrm{~g}$ com valor energético semelhante. O conteúdo total de compostos fenólicos, por porção, de SHB foi de $11.198 \mathrm{mg}$ e de CHB de $9.483 \mathrm{mg}$, conteúdo aproximadamente 18\% maior com a adição das especiarias. Ambas as formulações mostraram boa aceitação pelos provadores com base no índice de aceitabilidade, com mais de $75 \%$ em todos os parâmetros. A seleção de ingredientes específicos, ricos em compostos bioativos, pode impactar positivamente o conteúdo de polifenóis em produtos de panificação sem comprometer as características sensoriais.

Palavras-chave: Especiarias; Polifenóis; Análise sensorial; Panificação.

\section{Resumen}

Las especias son fuentes importantes de compuestos fenólicos y, cuando se consumen regularmente en la dieta, contribuyen a los efectos beneficiosos de estos compuestos bioactivos sobre la salud. El objetivo de este estudio fue elaborar un producto de panadería, pan de miel, sin especias, pan de miel control (CHB) y con adición de diferentes especias, pan de miel com especias (SHB), estimar el aporte de polifenoles y evaluar la aceptación sensorial de las dos formulaciones. La composición de macronutrientes se calculó utilizando la Tabla Brasileña de Composición de Alimentos y el contenido de compuestos fenólicos se calculó con base en la base de datos Phenol-Explorer 3.0. Para la evaluación sensorial se estableció un panel de consumidores y se aplicó una escala hedónica de siete puntos para: aroma, textura, apariencia, sabor y aceptación total. Cada formulación produjo setenta porciones de $16 \mathrm{~g}$ con valor energético similar. El contenido total de compuestos fenólicos, por ración, de SHB fue de 11,198mg y de CHB de $9,483 \mathrm{mg}$, aproximadamente un 18\% más alto con la adición de especias. Ambas formulaciones mostraron una buena aceptación por parte de los catadores en base al índice de aceptabilidad, con más del 75\% en todos los parámetros. La 
selección de ingredientes específicos, ricos en compuestos bioactivos, puede impactar positivamente el contenido de polifenoles en los productos de panadería sin comprometer las características sensoriales.

Palabras clave: Especias; Polifenoles; Evaluación sensorial; Panadería.

\section{Introduction}

Food consumption is a daily activity necessary for all living beings to guarantee their development and growth the habitual diet provides, in addition to macronutrients and micronutrients, there are other substances, non-nutrients, called bioactive compounds ( $\mathrm{Liu}, 2013)$. The presence of bioactive compounds in food led to the concept of "functional food". Despite different definitions can be described as food or ingredient that, in addition to basic nutritional functions, produces metabolic and / or physiological effects and/or beneficial health effects when consumed in a regular basis. In addition, it should be safe for consumption without medical supervision (Konstantinidi \& Koutelidakis, 2019).

Bioactive compounds are widely recognized for their health-promoting properties and technological applications, as they have been linked to modulation of inflammatory processes and of antioxidant defence mechanisms. Among them, phenolic compounds, present in different fruits, vegetables, and whole grains comprehend one of the largest groups (Fraga et al., 2019). Polyphenols can be categorized into several classes, such as flavonoids, phenolic acids, and tannins.

Flavonoids are compounds widely distributed in the plant kingdom and are found in fruits, vegetables, seeds and other parts of the plant mainly in the form of glycosides. Flavonoids can be further classified as flavonols, flavones, flavanones, flavanols, isoflavones, and anthocyanidins. Phenolic acids consist of two groups, derivatives of hydroxybenzoic acid or hydroxycinnamic acid. They are characterized by having a benzene ring, a carboxylic group and one or more hydroxyl and / or methyl groups, conferring antioxidant properties to the molecule (Balasundram et al., 2006; Fraga et al., 2019).

The use of dietary components as natural antioxidants in baked products is promising and enrichment with fruits and vegetables, or its by-products, has been widely studied (Xu et al., 2019; Salehi \& Aghajanzadeh, 2020). In Brazil, recent estimative shows that french bread and cake, pies and cookies contributed to 6,9\% and 3,0\% of total energy intake (Louzada et al 2015). Polyphenol incorporation can increase the antioxidant activity and contribute to some clinical settings, such as decrease of postprandial serum glucose. However, fruit and vegetable inclusion in formulations can sometimes alter sensory aspects resulting in negative perceptions by the consumer (Ou et al., 2019; Carvalho et al., 2020).

Among alternatives to fruit and vegetables, are herbs and spices. In general, spices have high concentrations of bioactive compounds, in particular phenolic compounds. Additionally, spices confer pleasant flavor when incorporated in small quantities in preparations, contributing to their aroma and color (Yashim et al., 2017; Guiné \& Gonçalves, 2016). According to a ranking made using Phenol-Explorer database, spices are rich sources of phenolics. Among the one hundred foods with the highest contents, cloves ranked first with $15,188 \mathrm{mg}$ phenolics per $100 \mathrm{~g}$. Dried ginger appeared at $37^{\text {th }}$ position with 202mg phenolics per 100g, cinnamon at position $68^{\text {th }}$ with $48 \mathrm{mg}$ phenolics per 100g (Pérez-Jiménez et al., 2010).

Therefore, considering the contribution of bread and other baked products to total energy intake of the Brazilian population and the possibility of increasing bioactive compounds by the addition of specific ingredients, the present study aimed to elaborate a baked product (honeybread), with and without the addition of spices, estimate the polyphenol content and evaluate sensory acceptance in final formulations.

\section{Methodology}

An experimental study was conducted in combination with sensory analysis (Pereira et al., 2018). For honeybread formulations, ingredients were purchased in retail markets in the city of Rio de Janeiro and transported to the Laboratory of Dietetic Technique of the Institute of Nutrition at UFRJ. A technical preparation sheet was developed for both formulations, 
for process control, and reproducibility (Akutsu et al., 2005). A basic formulation was developed for both control honeybread (CHB), without spices, and honeybread with spices (SHB), which included powdered cloves, cinnamon, nutmeg, ginger, and turmeric. Table 1 describes the formulation of both control and spiced honeybreads. The $60 \%$ chocolate was melted and used for coating as traditionally applied in honey bread formulations.

Table 1. Basic formulation for control honeybread (CHB) and spiced honeybread (SHB).

\begin{tabular}{lcc}
\hline INGREDIENTS & CHB & SHB \\
& g/ ml (\%) & g/ ml (\%) \\
\hline Potato starch & $255(22,4)$ & $255(22,2)$ \\
Cocoa powder & $40(3,5)$ & $40(3,5)$ \\
Oat bran & $40(3,5)$ & $40(3,5)$ \\
Brown sugar & $55(4,8)$ & $55(4,8)$ \\
Clove, powder & - & $2(0,2)$ \\
Cinnamon, powder & - & $2(0,2)$ \\
Nutmeg, powder & - & $2(0,2)$ \\
Ginger, powder & - & $2(0,2)$ \\
Turmeric, powder & - & $2(0,2)$ \\
Honey & $90(7,9)$ & $90(7,8)$ \\
Skim milk & $300(26,3)$ & $300(26,1)$ \\
Vegetable oil & $60(5,3)$ & $60(5,2)$ \\
Vanilla extract & $15(1,3)$ & $15(1,3)$ \\
Baking powder & $5(0,4)$ & $5(0,4)$ \\
Chocolate 60\% & $280(24,6)$ & $280(24,3)$ \\
\hline TOTAL & $1140(100)$ & $1150(100)$ \\
\hline
\end{tabular}

Source: Authors.

Macronutrient composition of both formulations was calculated using the Brazilian Food Composition Database (Unicamp, 2011). Phenolic compounds were estimated based on the Phenol-Explorer 3.0 database (Rothwell et al., 2013). Sensory evaluation was approved by the Ethics Board Committee of University Hospital (protocol 79790517.8.0000.5257). All tests were conducted in a single day. Honeybreads were prepared in the same day and maintained in room temperature $\left(25^{\circ} \mathrm{C}\right)$ during testing, as usually consumed.

A single serving (16g), of each formulation was placed on a white, plastic dish labelled with random 3-digit numbers and randomly assigned to each member of the consumer panel. Drinking water was provided for subjects to rinse their mouth between formulations. Tasters were recruited from staff and students at the University. Demographic and personal information such as age, sex, and frequency of consumption of this type of baked product was collected. The evaluation of honeybread sensory attributes included total acceptability, aroma, texture, appearance, and taste, scored on a Hedonic Scale. Each score rated the samples on a 7-point scale from 1 (lowest) to 7 (highest). For acceptability index (AI \%) it was used the following equation: $\mathrm{AI}(\%)=(\mathrm{A} x$ 100) / B (Teixeira et al., 1987).

Mean and standard deviation was calculated for each attributed evaluated and differences between CHB and SHB were analysed using t-student test with $95 \%$ confidence level. 


\section{Results and Discussion}

Both formulations, CHB and SHB, yielded seventy (16g each) servings with 52 and 53 kcals, respectively. Table 2 describes macronutrient composition based on formulation used for both control and spiced honeybreads which did not differ between formulations. Macronutrient content of CHB and SHB were slightly different from polyphenol enriched baked products by the addition of fruits and vegetables (FV) (Gómez \& Martinez, 2018). In general, carbohydrate content was approximately 53\% of calories in our study and for FV enriched cakes it could vary from 45 up to $67 \%$ depending on the FV used as replacement for regular flour. Protein content was also similar to cakes that used apple, cranberry and carrot powders, for example, around $5-5,5 \%$. The main difference observed was on total fat content; our formulations resulted in an average of $40 \%$ whereas the FV enriched cakes tended to show a total fat content of $23 \%$ (Gómez \& Martinez, 2018).

Table 2. Macronutrient composition of control honeybread (CHB) and spiced honeybread (SHB).

\begin{tabular}{|c|c|c|c|c|c|c|}
\hline & \multicolumn{3}{|c|}{ CHB } & \multicolumn{3}{|c|}{ SHB } \\
\hline & $\mathrm{g} / 100 \mathrm{~g}$ & g/ serving (16g) & $\% \mathrm{DV}^{2}$ & $\mathrm{~g} / \mathrm{100g}$ & g/ serving (16 g) & $\% \mathrm{DV}^{2}$ \\
\hline Energy (kcal) & 325 & 52 & 3 & 331 & 53 & 3 \\
\hline Carbohydrates & 43,8 & 7,0 & 2 & 43,8 & 7,0 & 2 \\
\hline Proteins & 4,3 & 0,7 & 1 & 4,3 & 0,7 & 1 \\
\hline Total fat & 14,4 & 2,3 & 4 & 15,6 & 2,5 & 5 \\
\hline Saturated fat & 5,6 & 0,9 & 4 & 5,6 & 0,9 & 4 \\
\hline Dietary fiber & 4,3 & 0,7 & 3 & 4,3 & 0,7 & 3 \\
\hline
\end{tabular}

Source: Daily Value (\%DV) in (g/ serving) based on a 2,000 kcal daily diet (Brasil, 2003). Source: Authors.

Trentin et al. (2020) also showed increased nutritional quality and antioxidant activity of regular wheat flour partially substituted by ora-pro-nobis flour. In a dose dependent manner, the substitution of $0,10,20$ and $30 \%$ regular flour for ora-pronobis flour increased total phenolic content from 0.56 to 7.6, 14.51 and 21.5 gallic acid equivalents per gram, respectively. Additionally, the flour blends resulted showed characteristics suitable for use in biscuits, baked cakes and breads. In another model, Carvalho et al. (2020) substituted $10 \%$ of regular wheat flour for green papaya peel flour in the formulation of breads. Despite the higher nutritional quality in the papaya flour, the bitterness in the final product was a limitation. In this way, nonconventional plants such as ora-pro-nobis, along with fruits, vegetables, and spices, could be used to increase nutritional quality and polyphenol content in baked products but sensory aspects should be carefully considered.

Dietary fiber of both $\mathrm{CHB}$ and SHB was $4,3 \mathrm{~g} / 100 \mathrm{~g}$. This could be the result of the inclusion of oat bran in our formulation, even though only $40 \mathrm{~g}$ was used for a seventy servings batch, oat bran is a rich source of dietary fiber. According to the Brazilian regulation, a product with a minimum of $3 \mathrm{~g}$ of dietary fiber per $100 \mathrm{~g}$ of product may classify as a source of fiber (BRASIL, 1998). In addition, oat bran contributed, slightly, to the polyphenol content since many phenolic acids are present in whole grains, especially in the outer layers. According to a polyphenol ranking published by Pérez-Jiménez et al. (2010), whole grain oat flour ranked in 74th place, with $37 \mathrm{mg}$ phenolics per $100 \mathrm{~g}$.

Table 3 describes phenolic content provided by each ingredient used in both control and spiced honeybreads, per serving. Total phenolic content was estimated in 11,199mg per serving for SHB and in 9,483mg per serving in CHB (Table 3). Four subgroups were identified in CHB, flavanols, flavonols, hydroxybenzoic acids and hydroxycinnamic acids. In SHB, in addition to the subgroups mentioned above it was identified curcuminoids. When analysing by major subgroups the main differences between formulations can be observed for phenolic acids, where CHB contributed with 0,862mg per serving and 
SHB with 2,562mg per serving. Table 4 describes the subclasses of polyphenols provided in both control and spiced honeybreads, per serving, as well as their proportion (\%) to total phenolic content. Even though flavonoids represent most of the bioactive compounds, in SHB curcuminoids resulted in a $14 \%$ contribution to the total polyphenol content.

Table 3. Phenolic compounds in one serving (16g) of control honeybread (CHB) and spiced honeybread (SHB).

\begin{tabular}{lll}
\hline INGREDIENTS & CHB & SHB \\
\hline Potato starch & 0,0000 & 0,0000 \\
Cocoa powder & 3,1353 & 3,1353 \\
Oat bran & 0,0751 & 0,0751 \\
Brown sugar & 0,0000 & 0,0000 \\
Clove, powder & - & 0,1486 \\
Cinnamon, powder & - & 0,0057 \\
Nutmeg, powder & - & 0,0047 \\
Ginger, powder & - & 0,0044 \\
Turmeric, powder & - & 1,5524 \\
Honey & 0,0000 & 0,0000 \\
Skim milk & 0,0000 & 0,0000 \\
Vegetable oil & 0,0000 & 0,0000 \\
Vanilla extract & 0,0000 & 0,0000 \\
Baking powder & 0,0000 & 0,0000 \\
Chocolate 60\% & 6,2726 & 6,2726 \\
Total phenolics & $\mathbf{9 , 4 8 3}$ & $\mathbf{1 1 , 1 9 8}$ \\
(mg/ serving) & & \\
\hline
\end{tabular}

Source: values calculated based on Phenol-Explorer. Source: Authors.

Regarding polyphenol content, the addition of spices, $10 \mathrm{~g}$ in total, contributed to an extra $1,715 \mathrm{mg}$ of phenolics per serving, an $18 \%$ increase in SHB compared to CHB. The amount of phenolics provided by the inclusion of spices may seem small but considering that it only refers to one $16 \mathrm{~g}$ serving of the honeybread we can speculate that if spices are also used in other preparations in a daily basis, a significant increase could be obtained. Przygodzka et al. (2016) showed that spices addition to rye-buckwheat cakes, even though in lower amounts $(2 \mathrm{~g})$ than used in this study, resulted in higher antioxidant activity and phenolic content compared to control cakes. Among the spices tested, vanilla, commercial spice mix for gingerbread, cinnamon, nutmeg, and cloves were the ones with higher acceptability after sensory analysis.

Although not a result of spices addition, it is important to mention cocoa products contribution to the polyphenol content since cocoa powder was used in the batter and $60 \%$ melted chocolate used for coating. Cocoa powder was ranked in fourth place, with 3448mg per 100g and dark chocolate in eighth place, providing approximately 1664mg per 100g (PérezJiménez et al., 2010). When choosing a 60\% cocoa chocolate instead of a regular Milk chocolate, our formulation resulted in 4 $\mathrm{g}$ of chocolate per serving which, alone, provided 6,2726mg polyphenols. In this way, it is important to mention that, when developing new products, inclusion of each ingredient must be carefully considered to increase polyphenol intake and health benefits. 
Table 4. Subgroups of phenolic compounds in one serving (16g) of control honeybread (CHB) and spiced honeybread (SHB)

\begin{tabular}{lll}
\hline COMPOUNDS & CHB & SHB \\
\hline FLAVONOIDS & $8,020(85 \%)$ & $8,020(72 \%)$ \\
Flavanols & $0,600(6 \%)$ & $0,615(5 \%)$ \\
Flavonols & $\mathbf{8 , 6 2 0}(\mathbf{9 1 \%})$ & $\mathbf{8 , 6 3 5}(\mathbf{7 7 \%})$ \\
Total Flavonoids & & \\
PHENOLIC ACIDS & $0,004(0 \%)$ & $0,136(1 \%)$ \\
Hydroxybenzoic acids & $0,859(9 \%)$ & $0,875(8 \%)$ \\
Hydroxycinnamic acids & $0,000(0 \%)$ & $1,552(14 \%)$ \\
Curcuminoides & $\mathbf{0 , 8 6 3 ( 9 \% )}$ & $\mathbf{2 , 5 6 3 ( 2 3 \% )}$ \\
Total phenolic acids &
\end{tabular}

Source: values calculated based on Phenol-Explorer. Source: Authors.

The results for the sensory evaluation showed similar results, between CHB and SHB, with no statistical differences for all parameters. Mean values for aroma were 6,2 $\pm 0,86$ and 6,1 $\pm 0,92$, respectively. For texture, formulations rated 5,3 \pm 1,34 and 5,3 $\pm 1,32$, respectively, appearance rated $6,4 \pm 0,68$ and $6,3 \pm 0,82$, respectively, and for taste 5,5 $\pm 1,14$ and $5,4 \pm$ 1,35 , respectively. Partial substitution of regular wheat flour for green papaya flour resulted in similar results for taste $(5,58)$ and global appearance $(6,23)$ (Carvalho et al., 2020). The authors stated that the tasters complained of a bitter taste in the fruit added formulation, however, despite the similar value obtained no specific complaint was registered in our work.

Among the attributes evaluated, aroma and appearance received higher scores than texture and taste. The aroma could have been influenced by the chocolate coating of the honeybreads making the spices addition less perceptible to the tasters. Taste, however, results from a combination of sensorial experiences, being influenced by texture, aroma, environmental aspects such as temperature, as for flavour itself. In this way, aroma alone is recognized as an important attribute towards product acceptability (Favarão, 2017). Which could partially explain the high acceptability index obtained by both formulations even with a relative low mean value for taste.

Table 5 describes sensory evaluation results and acceptability index of both control and spiced honeybreads, per serving. Our panel for sensory evaluation consisted of 91 female volunteers and 19 male volunteers from which $74 \%$ stated to be honeybread consumers. Total acceptability can be comprehended as the combination of aspects that reflects consumers' first impression of a product (Gomes \& Penna, 2009). Considering a 7-point scale averages of 5,7 $\pm 0,94$ for CHB and 5,6 $\pm 1,11$ for SHB were positive.

For product development, acceptability index (AI) is also important since it tries to predict consumer behaviour toward the product. When AI is higher than 70\% is considered "good" among consumers (Moscatto et al., 2004). Considering that both formulations resulted in $\mathrm{AI}$ of $75 \%$, or higher, that the products would have good acceptability. Our results are similar to other studies with nutritional enriched formulations for baked products. Lima et al. (2020) an AI of 77\% in a bread with $10 \%$ substitution of regular wheat flour for soursop residue flour. Cookies made using different ratios of regular wheat flour and guava peel flour also resulted in AI higher than 70\% (Bertagnolli et al., 2014). 
Table 5. Acceptability index of control honeybread (CHB) and spiced honeybread (SHB).

\begin{tabular}{lcc}
\hline & $\begin{array}{c}\text { CHB } \\
(\boldsymbol{\%})\end{array}$ & $\begin{array}{l}\text { SHB } \\
(\boldsymbol{\%})\end{array}$ \\
& & \\
\hline Aroma & 88,5 & 87,1 \\
Texture & 75,7 & 75,7 \\
Apearance & 91,4 & 90,0 \\
Taste & 78,5 & 77,1 \\
Total acceptability & $\mathbf{8 1 , 4}$ & $\mathbf{8 0 , 0}$ \\
\hline
\end{tabular}

Source: Authors.

\section{Conclusion}

Selection of specific ingredients and inclusion of bioactive compounds rich matrixes such as fruits, vegetables, and spices, when developing new formulations, can positively impact polyphenol content in baked products. In addition to the use of spices, that increased in approximately $18 \%$ phenolic estimates, cocoa powder and dark chocolate could have contributed to the aroma and acceptability index along with its polyphenol content. Although spices are traditionally used in culinary science to enhance sensory attributes no significant impact between formulations were observed. The inclusion of spices to baked products could result in products with higher phenolic compounds, good acceptability with little impact in sensory attributes.

\section{Acknowledgments}

We thank Instituto de Nutrição Josué de Castro for the use of its facilities during the research.

\section{References}

Akutsu, R. D. C., Botelho, R. A., Camargo, E. B., Sávio, K. E. O., \& Araújo, W. C. (2005). The technical cards as quality instrument for good manufacturing process. Revista de Nutrição, 18(2), 277-279. https://doi.org/10.1590/S1415-52732005000200012.

Balasundram, N., Sundram, K. \& Samman, S. (2006). Phenolic compounds in plants and agri-industrial by-products: Antioxidant activity, occurrence, and potential uses. Food Chemistry, 99(1), 191-203. .https://doi.org/10.1016/j.foodchem.2005.07.042.

Bertagnolli, S. M. M., Silveira, M. L. R., Fogaça, A. de O., Umann, L. \& Penna, N. G. (2014). Bioactive compounds and acceptance of cookies made with Guava peel flour. Food Science and Technology, 34(2), 303-308. https://doi.org/10.1590/fst.2014.0046.

BRASIL (1998). Agência Nacional de Vigilância Sanitária (ANVISA). Portaria $\mathrm{n}^{\circ} 27, \quad$ de $13 \quad$ de janeiro de 1998. http://bvsms.saude.gov.br/bvs/saudelegis/svs1/1998/prt0027_13_01_1998.html

BRASIL (2003). Agência Nacional de Vigilância Sanitária (ANVISA). RDC $\mathrm{n}^{\circ} \quad 360, \quad$ de 23 de dezembro de 2003. http://bvsms.saude.gov.br/bvs/saudelegis/anvisa/2003/rdc0360_23_12_2003.html

Carvalho, J. B., Marques, K. H. S. R., Mesquita, A. A., Paula, G. H. de, Lima, M. S. de, Ferreira, S. V., Medeiros, J. S., Teixeira, P. C., Nicolau, E. S. \& Silva, M. A. P. da. (2020). Chemical and functional properties of green papaya skin submitted to dry in different temperatures and application in breads. Research, Society and Development, 9(5), e29953154. https://doi.org/10.33448/rsd-v9i5.3154.

Favarão, V. Z. (2017). Teste de perfil descritivo quantitativo de aroma e sabor-estudo de caso no café, Trabalho de Conclusão de Curso, Universidade Tecnológica Federal do Paraná, Mourão, RS, Brasil. Disponível em: http://repositorio.roca.utfpr.edu.br/jspui/handle/1/7257.

Fraga, C. G., Croft, K. D., Kennedy, D. O. \& Tomás-Barberán, F. A. (2019). The Effects of Polyphenols and Other Bioactives on Human Health. Food \& Function, 10(2), 514-528. https://doi.org/10.1039/c8fo01997e.

Gomes, R. G., \& Penna, A. L. B. (2009). Características reológicas e sensoriais de bebidas lácteas funcionais. Semina: Ciências Agrárias, 30(3), 629-646. https://doi.org/10.5433/1679-0359.2009v30n3p629.

Gómez, M., \& Martinez, M. M. (2018). Fruit and Vegetable By-Products as Novel Ingredients to Improve the Nutritional Quality of Baked Goods. Critical Reviews in Food Science and Nutrition, 58(13), 2119-2135. https://doi.org/10.1080/10408398.2017.1305946. 
Research, Society and Development, v. 10, n. 3, e13210312869, 2021

(CC BY 4.0) | ISSN 2525-3409 | DOI: http://dx.doi.org/10.33448/rsd-v10i3.12869

Guiné, R. P. F., \& Gonçalves, F. J. (2016). Bioactive Compounds in Some Culinary Aromatic Herbs and Their Effects on Human Health. Mini-Reviews in Medicinal Chemistry, 16(11), 855-866. https://doi.org/10.2174/1389557516666160211120540.

Konstantinidi, M., \& Koutelidakis, A. E. (2019). Functional Foods and Bioactive Compounds: A Review of Its Possible Role on Weight Management and Obesity's Metabolic Consequences. Medicines (Basel), 6(3), 8-19. https://doi.org/10.3390/medicines6030094.

Lima, D. V., Azevedo, O. O. da C., Silva, N. de S., Silva, G. S., Pontes, E. D. S., Aaújo, M. G. G. de, Pereira, D. E., Piovesan, N., Medeiros, R. G., So ares, J. K. B. \& Vieira, V. B. (2020) Development and sensory evaluation of added bread from soursop residue flour. Research, Society and Development, 9(1), e172911857. https://doi.org/10.33448/rsd-v9i1.1857.

Liu, R. H. (2013). Dietary Bioactive Compounds and Their Health Implications. Journal of Food Science, 78(1), 18-25. https://doi.org/10.1111/17503841.12101 .

Louzada, M. L. da Costa, Martins, A. P. B., Canella, D. S., Baraldi, L. G., Levy, R. B., Claro, R. M., Moubarac, J-C., Cannon, G. \& Monteiro, C. A. (2015). Ultra-processed foods and the nutritional dietary profile in Brazil. Revista de Saúde Pública, 49, 38. https://doi.org/10.1590/S0034-8910.2015049006132

Moscatto, J. A., Prudêncio-Ferreira, S. H. \& Hauly, M. C. O. (2004). Farinha de yacon e inulina como ingredientes na formulação de bolo de chocolate. Ciência e Tecnologia de Alimentos, 24(4), 634-640. https://doi.org/10.1590/S0101-20612004000400026.

Ou, J., Wang, M., Zheng, J. \& Ou, S. (2019). Positive and Negative Effects of Polyphenol Incorporation in Baked Foods. Food Chemistry, 284, 90-99. https://doi.org/10.1016/j.foodchem.2019.01.096.

Pereira, A. J., Shitsuka, D. M., Parreira, F. J. \& Shitsuka, R. (2008). Metodologia da pesquisa científica. UFSM. Disponível em: https://repositorio.ufsm.br/bitstream/handle/1/15824/Lic_Computacao_Metodologia-Pesquisa-Cientifica.pdf?sequence=1.

Pérez-Jiménez, J., Neveu, V. \& Scalbert, A. (2010). Identification of the 100 Richest Dietary Sources of Polyphenols: An Application of the Phenol-Explorer Database. European Journal of Clinical Nutrition, 64(3), 112-120. https://doi.org/10.1038/ejcn.2010.221.

Przygodzka, M., Zieliński, H., Ciesarová, Z., Kukurová, K. and Lamparski, G. (2016), Effect of selected spices on chemical and sensory markers in fortified rye-buckwheat cakes. Food Science \& Nutrition, 4:651-660. https://doi.org/10.1002/fsn3.329.

Rothwell, J.A., Perez-Jimenez, J., Neveu, V., Medina-Remon, A., M'Hiri, N., García-Lobato, P., Manach, C., Knox, C., Eisner, R., Wishart D.S. \& Scalbert, A. (2013). Phenol-Explorer 3.0: a major update of the Phenol-Explorer database to incorporate data on the effects of food processing on polyphenol content. Database (Oxford). https://doi.org/10.1093/database/bat070.

Salehi, F. \& Aghajanzadeh, S. (2020). Effect of dried fruits and vegetables powder on cakes quality: A review. Trends in Food Science \& Technology, 95, 162-172. https://doi.org/10.1016/j.tifs.2019.11.011.

Teixeira, E., Meinert, E. M. \& Barbetta, P. A. Métodos sensoriais. Análise sensorial de alimentos. Editora da UFSC, Florianópolis, 1987 , 66-119.

Trentin, M. M., Bampi, M. \& Dinon, A. Z. (2020). Nutritional and rheological evaluation of blends based on ora-pro-nóbis (Pereskia aculeata Miller) and wheat flour. Research, Society and Development, 9(11), e3469119728. https://doi.org/10.33448/rsd-v9i11.9728.

Unicamp, O. N. (2011). TACO-Tabela Brasileira de Composição de Alimentos. Editora: Fórmula, Campinas, SP. Disponível em: http://www.nepa.unicamp.br/taco/index.php

Xu, J., Wang, W. \& Li, Y. (2019). Dough properties, bread quality, and associated interactions with added phenolic compounds: A review. Journal of Functional Foods, 52, 629-639. https://doi.org/10.1016/j.jff.2018.11.052.

Yashin, A., Yashin, Y., Xia, X. \& Nemzer, B. (2017). Antioxidant Activity of Spices and Their Impact on Human Health: A Revie w. Antioxidants (Basel), 6(3). https://doi.org/10.3390/antiox6030070. 